\title{
Thinking about the Biodiversity Loss in This Changing World
}

\author{
Maria Rita Palombo (D)
}

check for

updates

Citation: Palombo, M.R. Thinking about the Biodiversity Loss in This Changing World. Geosciences 2021, 11, 370. https://doi.org/10.3390/ geosciences 11090370

Academic Editors: Philippe Claeys and Jesus Martinez-Frias

Received: 19 May 2021

Accepted: 31 August 2021

Published: 3 September 2021

Publisher's Note: MDPI stays neutral with regard to jurisdictional claims in published maps and institutional affiliations.

Copyright: (C) 2021 by the author. Licensee MDPI, Basel, Switzerland. This article is an open access article distributed under the terms and conditions of the Creative Commons Attribution (CC BY) license (https:/ / creativecommons.org/licenses/by/ $4.0 /)$.
IGAG-CNR Rome Secondary Office c/o, Department of Earth Sciences, Sapienza University of Rome, 00185 Roma, Italy; mariarita.palombo46@gmail.com

\begin{abstract}
Extinction of species has been a recurrent phenomenon in the history of our planet, but it was generally outweighed in the course of quite a long geological time by the appearance of new species, except, especially, for the five geologically short times when the so-called "Big Five" mass extinctions occurred. Could the current decline in biodiversity be considered as a signal of an ongoing, human-driven sixth mass extinction? This note briefly examines some issues related to: (i) The hypothesized current extinction rate and the magnitude of contemporary global biodiversity loss; (ii) the challenges of comparing them to the background extinction rate and the magnitude of the past Big Five mass extinction events; (iii) briefly considering the effects of the main anthropogenic stressors on ecosystems, including the risk of the emergence of pandemic diseases. A comparison between the Pleistocene fauna dynamics with the present defaunation process and the cascading effects of recent anthropogenic actions on ecosystem structure and functioning suggests that habitat degradation, ecosystem fragmentation, and alien species introduction are important stressors increasing the negative impact on biodiversity exerted by anthropogenic-driven climate changes and their connected effects. In addition, anthropogenic ecological stressors such as urbanization, landscapes, and wildlife trade, creating new opportunities for virus transmission by augmenting human contact with wild species, are among the main factors triggering pandemic diseases.
\end{abstract}

Keywords: Anthropocene; biodiversity loss; ecosystem modifications; anthropogenic ecological stressors

\section{Introduction}

"We live in a zoologically impoverished world, from which all the hugest, and fiercest, and strangest forms have recently disappeared."

Wallace, 1876

The current annihilation of several species and biodiversity loss are increasing so quickly that many scientists believe that we are entering a dramatic extinction crisis, mainly caused by direct and indirect human pressure on natural environments and ecosystems, e.g., [1-4]. The extinction of species has been a recurring phenomenon throughout the history of our planet. Paleontologists estimate that during the about 3.5 Byr of the biosphere evolution as a united system of planetary life, about 3.96 billion species disappeared [5,6], but 4 billion species evolved on earth and the loss of species was generally balanced or outweighed by the appearance of new species, and biodiversity progressively increased. Massive biodiversity depletions (about an estimated loss of $75 \%$ of known species) over a geologically short time period during which species extinctions dramatically outnumbered originations (exceeding the average background extinction rate) have been rarely recorded in the biosphere's history. The most recent of the five major planetary extinction events occurred by the end of the Mesozoic Era, about 66 MYA. Therefore, the question arises whether the magnitude and the extinction rate of the extremely rapid decline in biodiversity could be regarded as the signal of an ongoing mass extinction (Sixth Mass Extinction), but several problems relate to the comparison of modern biodiversity loss, which is taking place in some centuries, with those that occurred in the past over periods ranging from less than 1 to more than 3 Myr. 
The major mass extinction events, the so-called "Big Five", occurred in PalaeozoicMesozoic geologically short times (end-Ordovician, $\sim 445 \mathrm{Ma}$, Late Devonian, $374 \mathrm{Ma}$, end-Permian, P-Tr, $\sim 252 \mathrm{Ma}$, end-Triassic, $\sim 200 \mathrm{Ma}$, and end-Cretaceous, K-T, $\sim 65 \mathrm{Ma}$ ), but at least six or more Neoproterozoic (Ediacaran, $\sim 542 \mathrm{Ma}$ ) and Palaeozoic-Mesozoic (endEarly Cambrian 486 Ma, end-Devonian, 360 Ma, Mid-Carboniferous, 323 Ma, Middle Permian, $\sim 262 \mathrm{Ma}$, Early Jurassic, $\sim 180 \mathrm{Ma}$ ) mostly less severe events have been recorded, e.g., [7-11]. At those times, the extinction rate was particularly high: a massive depletion affected both marine and terrestrial ecosystems and about $75 \%$ to $96 \%$ of species and $35 \%$ to $57 \%$ of genera became extinct (Table 1). However, the magnitude of these extinctions may have been either higher or lower than estimated because a number of extinct and surviving species may have escaped from the estimate since they did not leave a tangible record [12]. This is particularly the case of the Proterozoic soft-bodied organisms that left a fossil record absolutely insufficient for knowing whether or not an End-Proterozoic mass extinction might have occurred, as well as the actual magnitude of the Ediacarian event [10]. The available data clearly highlight the severity of the "Big Five" mass extinctions that affected marine and terrestrial plants and animals with broad, global geographic distributions in one to tens of millions of years (but recent studies suggest 0.1 Ma for P-Tr [10]). Millions or tens of millions of years of biological recovery, sometimes punctuated by explosive radiation episodes, followed those events, e.g., [13,14]. During these times, biodiversity, particularly faunal diversity, persistently increased throughout time. Although the preQuaternary mass extinctions differ from each other in rate, magnitude, and complexity of dynamics, it is indubitable that the extinctions were triggered by natural events, such as sea-level and climate changes (including global warming and glacial phases), ocean anoxia and acidification, volcanism, large meteorite impacts, and other abiotic changes in the biosphere that negatively affected time by time many different marine and terrestrial lineages, e.g., [10,15-40] (Table 1).

During the Cenozoic, major extinction crises generally involved only some taxonomical groups, as, for instance, the "Grande Coupure" overturn in European mammal faunas [41] (dated to the 33.5 Ma glacial advance acme at the Eocene-Oligocene transition [42], and the Late Pleistocene Megafaunal Extinction that involved terrestrial large-bodied mammals all over the world (see below Section 2).

The purpose of this note is not to provide a critical synthesis of mass extinction events or an interpretation of the debated mechanisms that underpin them, but rather to provide some food for thought about the potential scenario of earth's biodiversity in the coming centuries, in light of the natural processes that led to the major episodes of biodiversity losses in the deep Palaeozoic-Mesozoic time and in the geologically much shorter Quaternary time. The response of organisms to the repeated Pleistocene climatic oscillations (particularly at the time of the major reorganization of earth's climate system known as the early to mid-Pleistocene transition (EMPT), e.g., [43], which markedly influenced terrestrial fauna and flora dynamics) could provide useful clues for better interpreting the potential impact of the present climate worming in an anthropogenic modified world. 


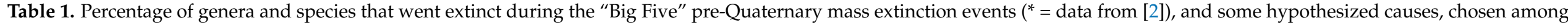
those that are either commonly acknowledged or debated.

\begin{tabular}{|c|c|c|c|c|c|c|}
\hline Event & $\begin{array}{l}\text { End (MYR } \\
\text { Ago) }\end{array}$ & Extent * (Myr) & Genera Estimated Lost * & Species Estimated Lost * & $\begin{array}{c}\text { Main Proposed Causes } \\
{[2,10,11,16-18,21-23]}\end{array}$ & Other Proposed Causes \\
\hline End-Ordovician & $\sim 443$ & $3.3-1.9$ & $57 \%$ & $86 \%$ & $\begin{array}{c}\text { Climate (alternating glacial and } \\
\text { interglacial episodes) but [24]; sea level } \\
\text { changes, regression followed by } \\
\text { transgression phases, triggering ocean } \\
\text { anoxia. }\end{array}$ & $\begin{array}{l}\text { Volcanism revealed by high } \\
\text { concentration of mercury traces, } \\
\text { e.g., [30]; changes in } \\
\text { atmospheric and oceanic } \\
\text { geochemistry, e.g., [31];. }\end{array}$ \\
\hline Late-Devonian & $\sim 359$ & $2.9-2$ & $35 \%$ & $75 \%$ & $\begin{array}{l}\text { Global cooling followed by global } \\
\text { warming; atmospheric carbon dioxide } \\
\text { decrease; sea level rise associated with } \\
\text { the spreas of anoxic waters from depth } \\
\text { shelf into shallow waters. }\end{array}$ & $\begin{array}{l}\text { Volcanism revealed by high } \\
\text { mercury concentration, e.g., [32], } \\
\text { methylmercury poisoning [33]; } \\
\text { meteorite impact, e.g., [34,35]; } \\
\text { UV-B radiation [36]. }\end{array}$ \\
\hline End-Permian & $\sim 251$ & $2.8-0.16$ & $56 \%$ & $96 \%$ & $\begin{array}{l}\text { Siberian volcanism leading to high } \\
\text { hydrogen sulphide, carbon dioxide levels, } \\
\text { and halogenous levels in the oceans and } \\
\text { atmosphere, but see }[25,26] \text {; ocean } \\
\text { acidification; global greenhouse warming. }\end{array}$ & Meteorite impact but $[19,20]$ \\
\hline end-Triassic (P-Tr) & $\sim 200$ & $8.3-0.6$ & $47 \%$ & $80 \%$ & $\begin{array}{l}\text { Increase in temperature likely caused by } \\
\text { magmatic activity (Central Atlantic } \\
\text { Magmatic Province) and resulting } \\
\text { augment of atmospheric carbon dioxide; } \\
\text { release of greenhouse gases causing } \\
\text { deep-ocean acidification; ocean } \\
\text { calcification crisis. }\end{array}$ & Ocean anoxia, e.g., [37] \\
\hline $\begin{array}{l}\text { End-Cretaceous } \\
\quad(\mathrm{K}-\mathrm{Pg})\end{array}$ & $\sim 65$ & $\begin{array}{l}\text { 2.5-less than } \\
1 \mathrm{Myr}\end{array}$ & $40 \%$ & $76 \%$ & $\begin{array}{l}\text { Long-term events: Deccan volcanism; } \\
\text { carbon dioxide, inducing warming; } \\
\text { tectonic uplift, accelerating erosion and } \\
\text { contributing to ocean eutrophication and } \\
\text { anoxic episodes. } \\
\text { Rapid event: Chicxulub asteroid impact } \\
\text { (Yucatàn Peninsula Mexico), causing } \\
\text { sudden cooling and a prolonged } \\
\text { cold winter. } \\
\text { see also [27-29] }\end{array}$ & $\begin{array}{l}\text { Ocean acidification and } \mathrm{Hg} \\
\text { toxicity, e.g., }[38-40]\end{array}$ \\
\hline
\end{tabular}




\section{What about the Biodiversity Fluctuation during the Quaternary?}

During most of the Pleistocene, local or regional extirpations and global extinctions of species were mainly related to climate-driven environmental changes. Several other factors influence the eco-evolutionary trends of terrestrial plants and, in particular, animals, as well as population and community responses to adverse environmental changes, facilitating or impeding species persistence in environments altered by changing climate and related physical factors. On continents, especially in the middle latitudes, the response of flora and fauna to climate stimuli and abiotical environment perturbations mainly depends on several factors, such as the geographical location, the climatic and microclimatic characteristics, the physiographic configuration of the territory, and on the nature and severity of ecological and physical barriers. For instance, the presence of barriers can influence the dispersal of a species if the environment conditions become unsuitable, hampering the geographical range translation and constraining the species to retreat from the original range to the population "core" area.

Whatever the flora and fauna dynamics at a regional scale could have been, several lines of evidence clearly indicate the pivotal relevance of the Pleistocene global climate changes in driving the modifications of plant and animal communities all over the world, particularly during EMPT, e.g., [44-59].

During the Pleistocene, for instance, climate forcing induced deep but gradual alterations and latitudinal displacements in terrestrial biomes that greatly influenced the dispersal and dispersion of mammalian species. Various species reacted to ecosystem disturbances by varying their geographic range in keeping with the displacement of biomes, acting as invasive species in the new territory. Major climate changes (i.e., changes in climate cyclicity) brought out perturbations in physical parameters and dispersal bioevents that merged "alien" species into previously existing communities. Both factors give rise to new intra-community dynamics by leading to the extinction/replacement of the most specialized species. The resulting unbalanced structure of the community stimulates new individual responses of other species. Competitive relationships constrained the faunal reorganization, leading to a new equilibrium and, de facto, causing ecosystems to significantly restructure during a long recovery period.

The most rapid Pleistocene mammal decline occurred at the end of the Pleistocene (roughly between fifty and ten thousand years ago) with the so-called Late PleistoceneHolocene megafaunal extinction (LPHME), which involved terrestrial large mammals of all continents, causing the disappearance of nearly $90 \%$ of genera and $85 \%$ of species weighing more than $44 \mathrm{~kg}$ (88\% of genera (14 genera) in Australia, 83\% (48) in South America, 72\% (28) in North America, 35\% (4) in Eurasia, and 21\% (7) in Africa) [60]. The cause of the late Quaternary extinctions has been a contentious matter and still remains a highly debated issue, e.g., [61-67] and references in those papers. Among the various hypotheses proposed to explain LPHME (overkilling, anthropogenic introduced diseases and predators, megadrought, extraterrestrial impacts, habitat loss, altered plant-animal equilibrium, and so on), the most debated are the two counterpoised hypotheses that consider climate changes and human hunting as the most likely drivers of this timetransgressive global extinction. Although prehistoric hunters are believed by some to have played a central role in LPHME, compelling evidence suggests that climatic and environmental changes were a major factor, especially in the demise of the less ecologically flexible species, e.g., [68-72]. Nonetheless, it is rational to suppose that human impacts (hunting, competition, habitat fragmentation, etc.,) likely increased the risk or accelerated the process of extinction for species already stressed by environmental changes, range contraction, and reduction of population number and size. The magnitude of LPHME does not reach the magnitude of a "mass extinction", but it could be regarded as part of a complex and ongoing extinction event that has increasingly accelerated, shifting from the Holocene to the still not formalized Anthropocene "epoch" [73,74] due to the growing impact of anthropogenic ecological stressors on species and ecosystems, e.g., [75]. 


\section{Are We on the Edge of a Sixth Mass Extinction?}

The hypothesis of a sixth incipient mass extinction was first suggested by [1]. The two authors, after having discussed the human influence on LPHME across continents, noted that the extinction continues today with an estimated annual extinction of about 17,000 to 100,000 species. As a result, many of the world's species, particularly the vast majority of those living in critically endangered environments, could become extinct within a few decades.

The actual significance of an extinction event, however, relates to both the extinction rate and magnitude, which gives us the background extinction rates (extinction, E, per million species-years, MSY). Knowing the current E/MSY of animal and plant species could be considered elementary because it depends on how many species became extinct over a certain time and their percentage with respect to the total number of species present on earth at that time, extrapolated to predict what the rate would be over a million years. However, some problems arise. First, the current extinction rate is extrapolated on the basis of species extinctions observed in an extremely short time (tens to hundreds of years), implicitly assuming that it may represent the average rate of extinction in one million years. However, a period of 1 Myr likely encompasses both relatively long periods during which the extinction rate was lower and short periods during which it was higher or even sensibly higher than the average rate. Accordingly, periods with lower or higher than average extinction rates are supposed to balance each other over $1 \mathrm{Myr}$. By contrast, shorter intervals have a bigger chance of catching extremes. Therefore, the validity of a comparison of extinction rates based on time intervals of different lengths is questionable (see, e.g., [2]).

Second, we only approximately know the number of current vertebrate species, especially mammals and birds, but we hardly know how many species exist among invertebrates, especially the number of species inhabiting remote regions or belonging to poorly known or even extremely diversified taxonomical groups (e.g., insects). Moreover, most have not yet been formally described or found out, especially among arthropods and other minor invertebrate groups, but also plants (not to mention fungi and microbes). A conservative estimate approximates 7 million living eukaryote species, mostly plants and animals (about $85 \%$ are terrestrial), excluding some taxonomical groups, such as bacteria, for instance [76,77].

In addition, estimates of the number of currently extinct species are based on the system and the conservative criteria followed by the International Union for Conservation of Nature (IUCN) [78]. Less than 3\% of modern species have been formally evaluated for extinction status and information about some species, even belonging to the major animal groups, is insufficient (Data Deficient Category) [79]. Consequently, the current loss of biodiversity is probably underestimated as it is based on the fossil record that hardly represents the real past biodiversity at any time. Although the fossil record of organisms living in unusual environments, such as deep oceanic water or remote regions, may be more extensive than that of modern species, we know very little about the true number of soft-bodied past species. Moreover, the fossil record, especially that of terrestrial species, is generally biased, even significantly, by taphonomic and diagenetic processes (see, e.g., [80,81], and references in those papers).

The actual value of the past extinction rate is difficult to ascertain. Estimates of background extinction rates are based on the estimated mean lifespans of species in the fossil record reported in non-mass-extinction intervals see [77], and references therein. The average life span is mostly based on marine invertebrates due to the finer and more continuous fossilization in marine sediments permitting a more robust collection of data [82]. Terrestrial vertebrates are likely to have a higher background extinction rate due to their limited potential for preservation, e.g., [83,84]. However, an average background extinction rate of $0.1-1 \mathrm{E} / \mathrm{MSY}$ is commonly accepted for fossil species, e.g., $[2,85,86]$.

Some authors [2] estimated extinction rates in many past 500-year intervals to reduce estimation biases and facilitate an evaluation of the current extinction rate in relation to the past background rate, making it easier to compare it with the rate in the most recent 
500 years. In the case of mammals, for which adequate data exist, the authors calculated a mean per-million-year fossil rate of about 1.8 E/MSY. The difficulty of documenting nascent paleontological evidence recorded in the sediments deposited over the past few hundred years further complicates estimating the actual extent of human-driven biodiversity loss in the last 500 years [2].

Two other aspects complicate comparing the magnitude of past and current extinctions. First, estimates of modern extinctions are made at the species level, while the genus level is generally preferred for the past. Second, the concept of species itself (or other taxonomic rank) is different if applied to modern (biological and phylogenetical concept) and fossil species (morphological concept, according to which specimens actually belonging to different species might be grouped into a single species or vice versa).

Furthermore, by combining paleontological and IUCN data (species status, ecology, and life history characteristics), some authors $[12,87]$ have demonstrated that the magnitude of ongoing biodiversity loss based on species with a fossil record is roughly half that based on all extant known species. Accordingly, the question of how many species could have evolved and become extinct in the past without leaving a fossil record, as well as what the background extinction rate was, arises once more.

Even when account is taken of these limits, it is apparent that the actual contemporaneous biodiversity decline is far from reaching the magnitude of the past mass extinction, but it is happening dramatically quickly, in a context where we can hardly envisage a forthcoming recovery. Available data highlight the quickening of species loss. For instance, according to the IPBES Global Assessment Report on Biodiversity and Ecosystem Services, 1 million species may currently be at risk of extinction $[88,89]$. Some authors have claimed that the contemporary extinction rate may be about 100 to 1000 times faster than the hypothetical average background extinction rate of 0.1-1 E/MSY. Recent analyses and data revisions [90] suggest that the current extinction rate may be about 100 times greater than the 0.1-1 E/MSY [2,91], forecasting a catastrophic scenario for future centuries.

Hundreds of articles have been published in scientific journals during the last couple of decades dealing with an up-and-coming mass extinction and its potential magnitude and extinction rate, some predicting an extinction of about $75 \%$ of extant species, e.g., [3,92,93] and references therein. This percentage would match that reached in some past mass extinction events during a period of millions to less than $1 \mathrm{Myr}$, or some hundred thousand years (as suggested for instance by some researchers for the $\mathrm{K}-\mathrm{Pg}$, end-Cretaceous, endPermian, and end-Triassic events [2], though the abruptness of the extinction has long been debated) (Table 1), but would be lost today in three centuries, see [2] for a discussion.

Although we are aware of the limited value of a comparison between E/MSY estimated over a few decades and over much longer periods, available data would suggest that, currently, the alleged E/MSY value is dramatically higher. The maximum extinction rate at the time of the Big Five mass extinctions would range from about 10 E/MSY (End-Permian event) to more than $1000 \mathrm{E} / \mathrm{MSY}$ (K-T event) [2]. The current E/MSY rate derived from the estimated number of assessed animal species extinctions [94] would be 30 times higher than the maximum (31,500 E/MSY) for the last 140 years and even significantly higher for the last 70 years $(85,287 \mathrm{E} / \mathrm{MSY})$. These estimates should be taken, however, with great caution and regarded as highly hypothetical, considering our imprecise knowledge of the real number of both living and threatened species.

According to the data published in 2020 by the International Union for Conservation of Nature (IUCN) [94], among the 618 species of animals lost since the end of the 19th century, about $67.64 \%$ were lost during the last 70 years (Figure 1). The 2020 global Living Planet Index [70] shows an average 68\% decrease (range: 73\% to 62\%) in population size between 1970 and 2016 in almost 21,000 populations of mammals, birds, amphibians, reptiles, and fishes monitored around the world.

The average number of vertebrate extinctions per year has increased over the last 70 years, while remaining relatively stable in mollusks and decreasing in the other monitored invertebrate taxonomic groups (Figure 1). 


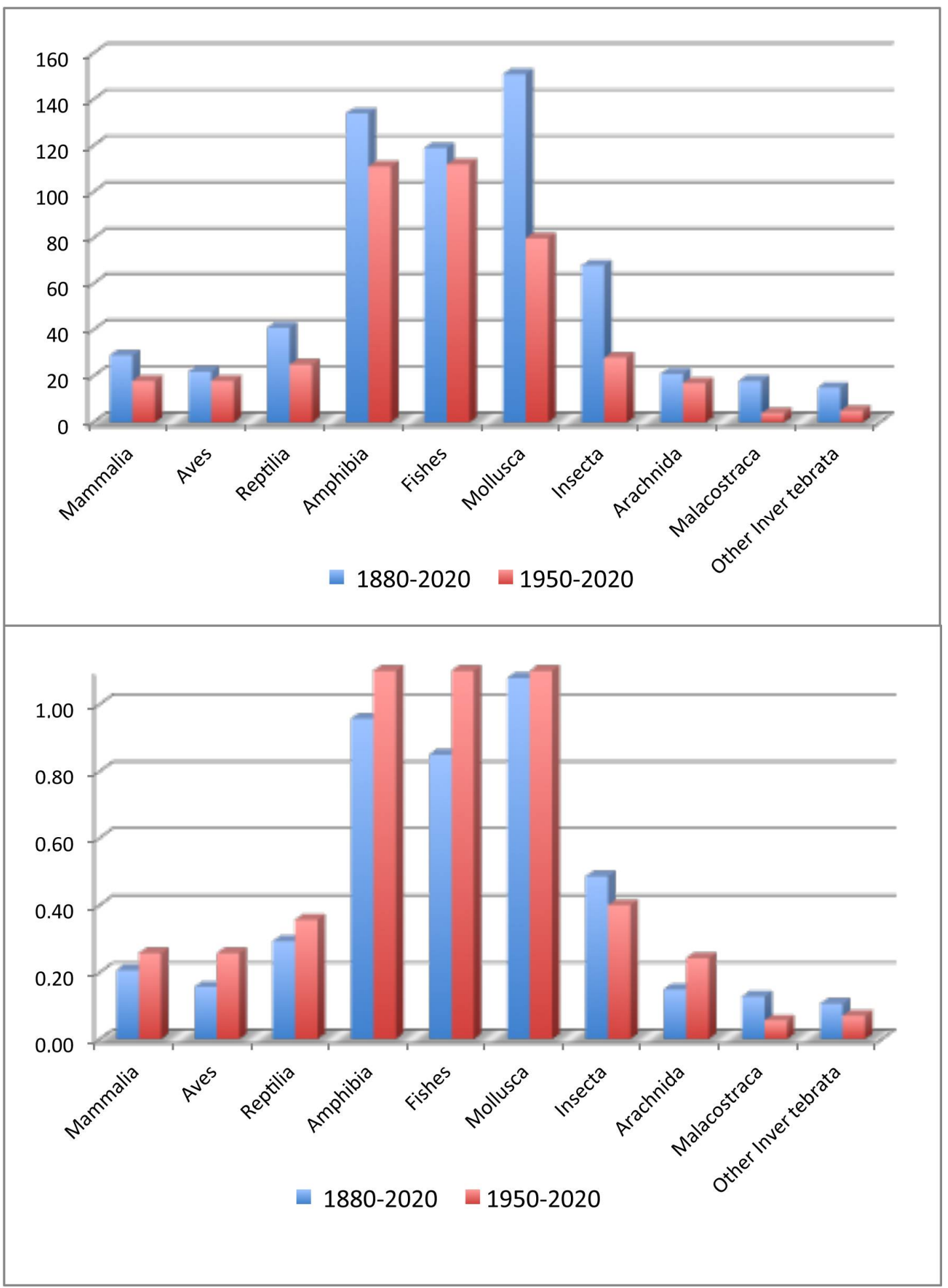

Figure 1. Comparison between the number of species extinct during the last 140 and 70 years in the major taxonomical groups of animals (data from [95]) (above), and between their annual average extinction rates (below).

The number of recently extinct animals and the percentage of critically endangered, endangered, and vulnerable species reported in the IUCN Red List are probably underestimated, even for well-known taxa such as birds, because the actual status of several species and subspecies is unknown, an unidentified number of existing species has not been 
identified or described, and percentages are calculated in relation to the overall number of the assessed species [94-96] (Figure 2).

Threatened Species/Assessed Species

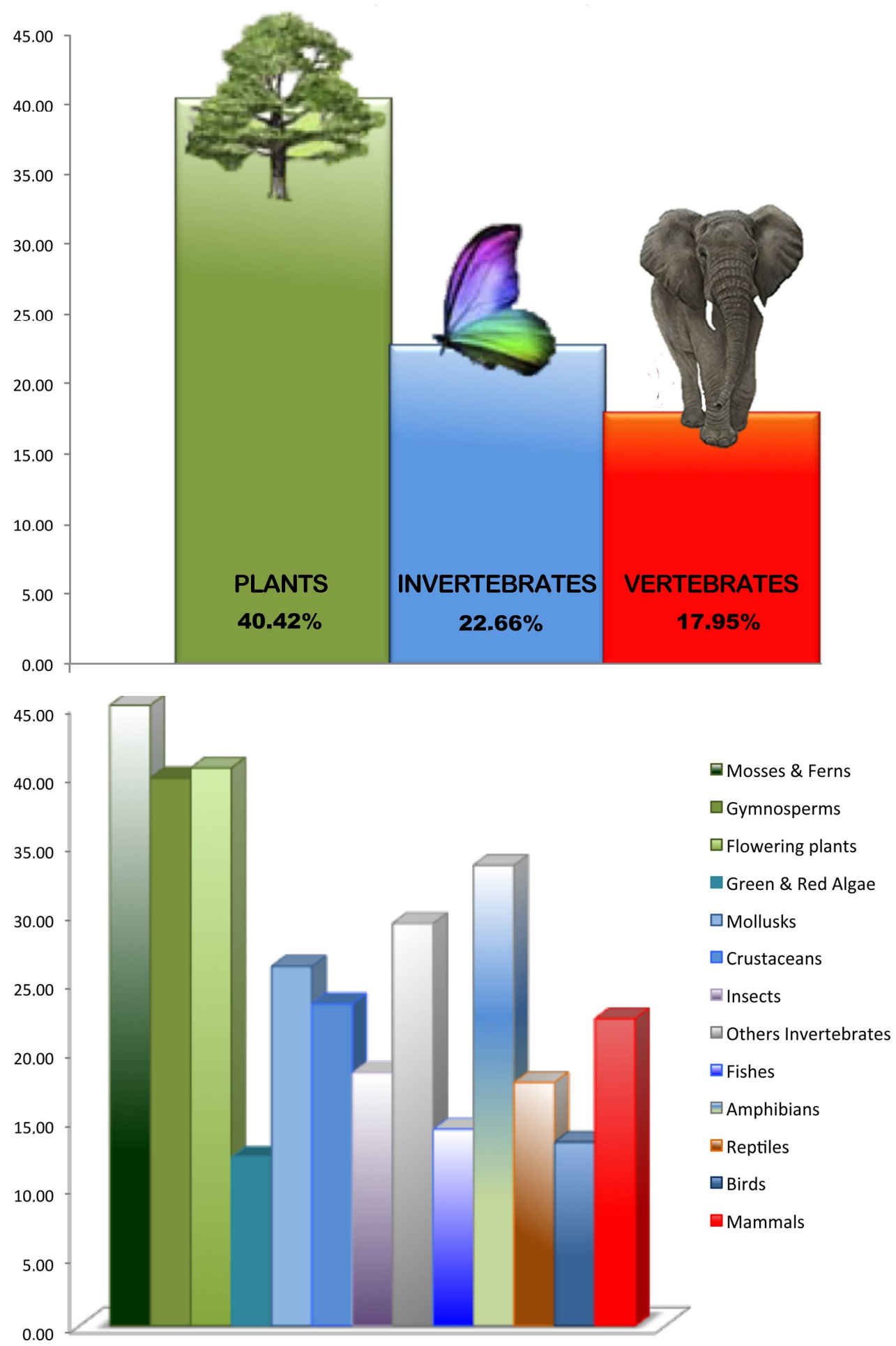

Figure 2. Percentage of the current number of threatened species evaluated in relation to the overall number of species assessed in the major groups of organisms by the IUCN animal Red list [94]. 
Although the IUCN Animal Red List is still far from being complete, it is a valuable source of information and depicts a possible scenario for the ongoing conservation status, extinction risk, and extinction numbers of the main animal groups.

Conversely, the IUCN Red List of plant threatened species is much less complete, and knowledge gaps increase [97]. The total number of wild plants is largely unknown, especially the number of plants from tropical regions, where most of the world's plants grow. In 2002, the number of vascular plants on the Red List (including in the Data Deficient and Least Concern categories) represented only 7\% of modern species [98]. In 2019 , only $\sim 7.5 \%$ (28,265 species) of known plant diversity was assessed on the IUCN Red List, and over 13,000 species (45.99\%), were assessed as Critically Endangered, Endangered or Vulnerable, and considered threatened with extinction in the wild [99].

Some useful pieces of information are provided by the IUNC Sampled Red List Index (SRLI) for Plants that analyzed a sample of $7000(0.018 \%)$ plants, randomly selected among the known plant species $(380,000)$. In 2010, the SRLI for Plants project, at the beginning of its activity, indicated that $20 \%$ of the assessed plants were threatened with extinction, but about a third were so poorly known that it was not possible to recognize whether they were threatened or not [95].

The actual number of threatened or lost plant species might be significantly different. Research in single geographic regions may provide further partial information about the flora's conservation status. For instance, Pitman and Jørgensen [100] focalized their analysis on tropical forests. They believed that the $13 \%$ value estimated at the time for the global flora threatened with extinction was significantly understated. Therefore, they tried to assess the missing tropical data from global patterns of plant endemism, finding "that as many as half of the world's plant species may qualify as threatened with extinction under the World Conservation Union (IUCN) classification scheme" [100] (p. 989). A recent estimate for Europe shows that $168(42 \%)$ of native species of trees (454 species) are threatened with extirpation at the European level, while for 57 species (12.56\%), information is inadequate to determine their conservation status [101].

Much more data are required to attempt an appraisal of the plant threatened species, which will be more accurate than those based on the currently available insufficient data (Figure 3).

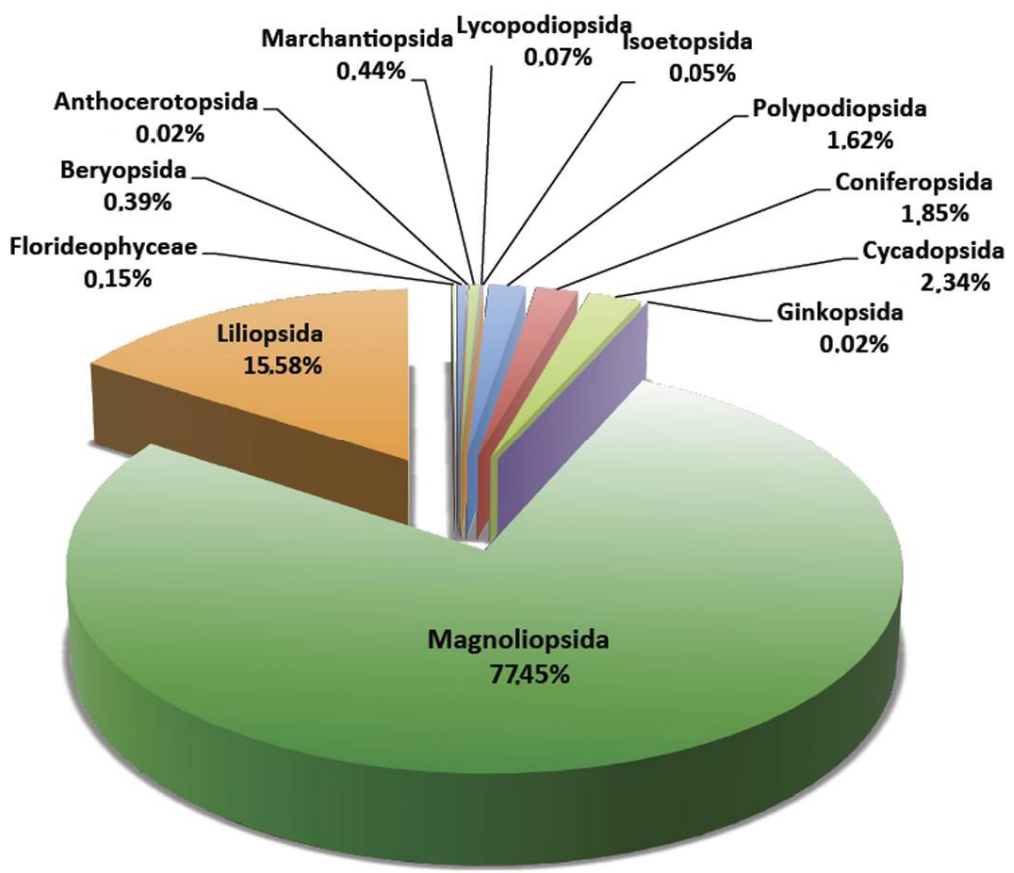

Figure 3. Percentage of the current number of threatened species evaluated in relation to the number of the plant species assessed in the IUCN plant Red List [102]. 
The idea of a continuous dropping of biodiversity toward a critical value finds some support in the trend shown over the last 50 years (1970-2020) by the Red List Index (RLI, which defines the conservation status of major species groups). RLI indicates that the survival probability decreased less for birds and mammals than for amphibians, and it is dramatically dwindling for cycads and especially corals [96].

The rate at which abiotic and biotic environmental parameters have been changing is likely to accelerate global biodiversity loss in the coming decades. The biosphere is an evolutionary, complex, functional system that may react unpredictably to external perturbations of an anomalous magnitude, but has demonstrated an unlimited resilience even in the face of massive perturbations. [103]. However, the rapidly increasing magnitude of anthropogenic-originated perturbations is currently threatening or annihilating several species unable to manage the environmental changes they are facing. The disappearance of a species (or a population) entails the progressive annihilation of other species due to the intimate ecological interactions of organisms in any ecosystem. The degradation and progressive loss of coral reefs, for instance, has dramatic consequences for the survival chances of the variety of organisms they support.

All in all, a good deal of evidence indicates that humans have caused a remarkable local population decline in plants and animals, contributed to the extinction of several species, and caused a threat to several others all over the world.

\section{Reflections on Contemporary Ecosystem Modifications and Fauna Depletion}

"The more we exploit nature, the more our options are reduced, until we only have one: to fight for survival."

Morris K. Udall

Over the past couple of centuries, earth's ecosystem structure and function have been dramatically altered, directly or indirectly, by human activities that have triggered anomalously rapid climate changes (i.e., a rapid increase in global warming) and the alteration of global biogeochemical cycles, which have increasingly affected the environment on all scales, sometimes augmenting the geological risk in vulnerable areas and the degradation of biodiverse habitats. Among others, the anthropogenic disturbance of the carbon cycle also deserves attention as a potential causal factor in global extinctions. Rothman [104] analyzed the significant changes in the carbon cycle over the last 540 million years, showing external perturbations (i.e., increased anthropogenic emissions of $\mathrm{CO}_{2}$ into the atmosphere) cause the cycle to respond by magnifying/augmenting its potential for stimulating earth system change. The author identified the thresholds in the carbon cycle that, if exceeded, would lead to a highly unstable environment, hypothesizing that "perturbations of earth's carbon cycle lead to mass extinction if they exceed either a critical rate at long time scales or a critical size at short time scales". The latter is happening today. In the past decades, anthropogenic-driven causal factors have been prompting profound modifications of ecosystems, more evident in the terrestrial realm, though neither landmasses today nor oceans are protected from a serious decline in biodiversity. Several ecological stressors, sometimes synergically acting, and related feedback processes, contribute to reducing the geographical range of various species, their population number and size, pushing them below the survival thresholds.

Most researchers deem global warming one among the pivotal factors causing local extirpations, global extinctions, and thus the loss of biodiversity. The actual impact of the in progress climate warming (anthropogenic driven and accelerated) on flora and fauna species (particularly on the less ecologically flexible) and its cascading effects on other species and ecosystem functioning is quite difficult to determine for the present and forecast for the future, e.g., [105]. However, it may be claimed that it might be more substantial than during most of the quaternary. During the Pleistocene, particularly in the boreal middle latitudes, repeated and opposing climate oscillations induced repeated spreads and retreats of plant populations, fragmentation of geographical distributions, and extirpations and extinctions of taxa, e.g., [55,106,107]. 
Several vagile animals (e.g., coleopters, birds, mammals) changed their geographic range according to the modified climatic gradient, the vegetation cover shift, and changes in water temperature and oceanic circulation, e.g., [48,108-110]. Conversely, intensive anthropization currently prevents the dispersal movements of most terrestrial mammals to escape from environmental conditions unsuitable for their own environmental tolerance. The increasing growth of human footprints in the ecological landscape, the conversion of natural and seminatural habitats for land-use, the widespread network of physical infrastructure (e.g., roads, nightlights, railways, etc.), deforestation, etc., have caused habitat fragmentation, particularly important in the most densely populated regions. Landscape connectivity is critical for ecosystem health and biodiversity conservation. As a result, any significant modification (reduction or annihilation) profoundly affects how mammals live and move across altered and fragmented landscapes, confines wild species within modified habitats or pushes some populations into unsuitable territories, and sensibly reduces or hampers the movement chances of terrestrial species, effectively impeding any displacement pattern comparable to past dispersal patterns. Overall, cumulative human pressure on the environment, habitat fragmentation, and land use changes, combined with climate-driven environmental changes, are critical drivers of species' local extirpation in the terrestrial realm, though other factors contribute to biodiversity decline (see below).

Although local extirpation does not always imply "global extinction", habitat fragmentation combined with climate-driven environmental changes, may nullify a population's (if not species) potential ability to colonize new and more suitable territories and maintain its survival potential, thereby increasing the extinction risk, e.g., [111,112]. Conversely, as highlighted by some authors [113] (p. 110), "greater dispersal and colonization abilities in the ocean may help some marine species to avoid global extinction, but only if habitat is convenient for colonization", even if greater rates of population-level extirpation are expected in the ocean due to the presence of species highly sensitive to the effect of climate warming. The current defaunation process, however, is more documented in the terrestrial realm, especially in freshwater ecosystems, than in the marine realm [114] and references therein.

The human pressures on the biosphere are rapidly growing due to the fast increase in population numbers ( 2 to 4 billion more people will possibly inhabit our planet by 2050 (may be 9.8 billion) and, consequently, in consumption rates and resource exploitation. The overharvesting of terrestrial and marine resources, the number of human-altered landscapes and their impact on flora and fauna community structure and equilibrium dynamics, the intentional or unintentional introduction of invasive-exotic species (including disease organisms) rapidly spreading and replacing native fauna and flora, genetic manipulation of species, reshaped selection pressure, and related ecological stressors are causing the degradation, destruction, and fragmentation of the world's richest ecosystems, tropical forests, wetlands, and savannahs. The dangerous effects of profound alterations caused by human activities over the course of less than a century are also becoming apparent in marine ecosystems, e.g., $[115,116]$ and references therein.

The current decline in plant and animal individuals within populations, the extinction of local populations, the species range contraction, and the local extirpation of key species are all caused by a variety of interconnected factors that have cascading effects on other species, preventing them from engaging in ecological interactions that are critical to their survival.

Although some of the natural ecological stressors acting today triggered or drove biodiversity loss in the past (e.g., major climate changes and related phenomena as documented in the Pleistocene that provide the best temporal resolution for analyzing the effects of climatic oscillation, but also in the Cenozoic, and for most of the Palaeozoic mass extinction events), human activities are dramatically exacerbating their importance. For instance, increases in temperature and sea level rise are typically expected during an interglacial period and have been particularly rapid since about the MIS16 glacial acme ( $\sim 650 \mathrm{ka}$, Middle Pleistocene), but increases as abrupt as those induced by the present 
trajectory of greenhouse gas emissions have never been recorded in the past. At the same time, climate change, and altered atmospheric circulation, combined with anthropogenic extensive landscape modification and degradation, increase the risk of natural disasters (e.g., storms, floods, and droughts) and cause the disappearance of the most vulnerable ecosystems. The massive and continuous introduction of alien, more flexible, and more competitive species alters the community equilibrium, triggering the extirpation of native species. The greater the human population is, the greater the demand for goods and services (water, food, resources, and energy) is. The increase in energy production, industrial and intensive agricultural activities (and, in turn, augmented greenhouse gas emissions, pollution, toxification, and oligotrophication), species overexploitation, and legal and illegal wildlife trade also have a notable negative impact on biodiversity.

As a result, under the effect of anthropogenic amplified or directly induced interplay between ecological stressors, species extirpations/extinctions could continue for centuries, increasing the threat of species and the biodiversity decline, severely affecting the future evolution of terrestrial and marine biota by changing process patterns and trajectory. Although ecosystems and biodiversity can recover on a geological temporal scale, the return to a normal state cannot be achieved on a human temporal scale. The advancing "sixth mass extinction" (whether or not the extinction rate is greater than the rate of past extinction events and whatever it should be in the upcoming future) will likely have critical effects on short-term environmental sustainability, affect the amount and availability of ecosystem goods and services that mankind requires for survival, and negatively influence human well-being.

The biodiversity intactness index (BII) [117] is a suitable indicator for appraising the biosphere integrity and the ability of ecosystems to provide benefits to people. BII estimates the average residual present in a region by analyzing the status of a large set of ecologically diverse animal and plant species and comparing the current average abundance of wild species and primary vegetation with their abundance in pre-modern or modern times. The index is particularly influenced by the effects of land use and related pressures, regarded by most as the principal drivers of biodiversity loss, e.g., [73,118-120]. The global average $\mathrm{BII}(79 \%)$ is lower than the limit $(90 \%)$ thought to ensure safe conditions, and is especially low in the regions with a long history of severe use of the landscape, such as Western Europe [95].

\section{Remarks}

It is challenging to assess the significance of the contemporary biodiversity decline with respect to the magnitude and rate of the past main extinction phases. The available data give us an approximate picture of the species that were extinct in the recent past and of those currently threatened. However, it is difficult to know whether or not there has been a balance between the rapid loss of biodiversity and any potential origination of new species. Some new extant species have been described continuously for centuries (currently, new species descriptions focus on insects and other invertebrates). However, our knowledge of the species that inhabit our marine and terrestrial ecosystems is largely imperfect. This makes it impossible to know whether a newly created species is truly new or if it was already present in the wild, making comparisons with the number of extinct/threatened species impossible. Scientific papers dealing with this subject are fewer. In a recently published paper [121], the author underlined the relevance of originations in mitigating biodiversity loss. On the basis of data about the average extinction rate during the Pleistocene, as in [122] (p. 47), and assuming an equivalence between the dynamics of the natural factors responsible for the Pleistocene and the current extinctions, the author stated that the annual rate of extinction of the species lost currently due to human activity is much lower than generally expected. According to the author, the extinction rate has been 
"only about 1.5 species for the last 500 years and....these losses have probably been equalled or surpassed by species born (speciation) during that time"

[122] (p. 243).

Whether one agrees or disagrees with the methodology used and the conclusions proposed (e.g., a lesson from the recent past clearly shows that global climate changes have been the primary driver of flora and fauna turnover, and that human activities dramatically amplify the impact on the biodiversity of the climate and the other natural stressors that have acted in the past), there is no doubt that we have to actively consider the appearance of new species. Unfortunately, no objective estimates are currently available or possible. Therefore, the true extinction rates of current biodiversity loss, as well as the true magnitude of the ongoing mass extinction, remain unaddressed.

Whatever the magnitude of the current biodiversity loss may be, a comparative analysis of the general conditions required for the past main extinction events, a disentangling of the relationship between extinction selectivity and extinction intensity, and a better understanding of the interacting feedback loops connecting the natural ecological stressors that drove biodiversity loss during geological time, may help improve our knowledge of the direct and indirect antropogenic role in triggering the Anthropocene biodiversity decrease.

A growing body of evidence shows that human activities have a global impact on the environment, and on ecosystem ecological characteristics and functions, which causes changes in the services that human societies rely on and jeopardizes human health and well-being. Climate change and altered natural ecological mechanisms, indeed, negatively impact the environment and biodiversity, but also the food systems, permitting in this globalized world the fast spread of disease disrupting agriculture and infecting wildlife. The greater the human population, the greater the pressure on the environment; most of the rules governing host-pathogen interactions are broken, increasing the risk of virus transmission to new hosts. As the Millennium Ecosystem Assessment [88] report has already underlined, "Many important human diseases have originated in animals, and so changes in the habitats of animal populations that are disease vectors or reservoirs, may affect human health, sometimes positively and sometimes negatively".

The incessant habitat deterioration and loss, the low landscape resilience, the widespreading urbanization, and, to some extent, the human wildlife trade are not only concurrent causes of population and species extirpations and extinctions, but also threatening factors that increase the risk of disease vector migrations, creating opportunities for disease transmissions by augmenting human contact with wild species. As some authors emphasize [4], increasing human-animal interactions are a driving factor in pathogen transfer, resulting in more potential for disease spreading to humans. Biodiversity decline, environment degradation, water insecurity, and human health are intimately linked [123]. The last example of this emerging menace to human health is the current pandemic coronavirus disease (COVID-19).

Humans are radically altering and modifying earth's system equilibrium, compromising the inherent ability of ecosystems to absorb equilibrium disturbances and restructure to maintain their critical functions. The continuous growth of human originated ecological stressors coupled with natural and stochastic disturbances is degrading ecosystem resilience, pushing ecosystems to cross the ecological threshold where even minor changes in environmental conditions may negatively upset their status. In those landscapes where ecosystems currently exhibit low resilience, environmental degradation threatens an increase in latent extinctions. Elsewhere, in areas where human pressure is currently moderate, and some connectivity is maintained, the BII is low but either higher than the global average value (Americas) or slightly increasing (Central Asia), still showing some potential for recovery. Paleontological and palaeoecological data show that in the past, during periods of climatic and environmental changes, the resilience of some ecosystems favored the slow, progressive recovery of biodiversity, suggesting focusing conservation strategies on improving both landscape and ecosystem resilience by reducing ecological stressors and increasing local connectivity, e.g., [124]. 
Properly understanding the past ecosystem dynamics and the factors promoting or hampering the resilience of vulnerable ecosystems, and accurately deciphering the complex network of mechanisms driving fauna dynamics during the Pleistocene may direct suitable conservation actions for biodiversity conservation in view of ongoing climate warming and habitat degradation. Evidence from the Quaternary period allows us to expand our imagination beyond the present and gain insights into the future scenario of earth's ecosystems through a lesson from the past. Although the contemporary loss of species cannot be recognized as a true mass extinction, we have to avoid the risk of a biodiversity decrease that could become more dramatic and serious within a few generations. Acquainted and focused conservation efforts and prevention could avert a massive decline in biodiversity and the subsequent cascading effects such as the deterioration of ecosystem services and, in turn, of human welfare. Humanity's wellness, indeed, depends on how healthy we preserve earth.

Whatever the extent of the ongoing biodiversity loss will be in the future (a major or a less impactual mass extinction, or merely a phase of marked decline and disappearance of some animal and plant groups), there is no doubt that many species still exist, many are originating, and some taxonomical groups are expanding.

The bioevents that have marked our planet's evolutionary history and led to the biodiversity known by Palaeolithic men, demonstrate how earth's system has overcome the most severe biological crises, finding new equilibria and progressively increasing its biodiversity. New groups of organisms have occupied new ecological niches or replaced extinct species in those already existing, in a continuous rebuilding of the structure and composition of ecosystems.

Overall, it is reasonable to expect that new species origins will ensure that earth regains its biodiversity on a much larger time scale than we are currently facing. But a question arises: will humanity, as we know it today, be a part of this scenario in a distant future?

Funding: This research received no external funding.

Institutional Review Board Statement: Not applicable.

Informed Consent Statement: Not applicable.

Data Availability Statement: Not applicable.

Acknowledgments: I thank the three anonymous reviewers for their comments and constructive criticism, and the editor for the valuable support.

Conflicts of Interest: The author declares no conflict of interest.

\section{References}

1. Leakey, R.E.; Lewin, R. The Sixth Extinction: Biodiversity and Its Survival; Phoenix Publishers: Phoenix, AZ, USA, $1995 ;$ pp. 1-271.

2. Barnosky, A.D.; Matzke, N.; Tomiya, S.; Wogan, G.O.; Swartz, B.; Quental, T.B.; Marshall, C.; McGuire, J.L.; Lindsey, E.L.; Maguire, K.C.; et al. Has the Earth's sixth mass extinction already arrived? Nature 2011, 471, 51-57. [CrossRef]

3. Payne, J.L.; Bush, A.M.; Heim, N.A.; Knope, M.L.; McCauley, D.J. Ecological selectivity of the emerging mass extinction in the oceans. Science 2016, 353, 1284-1286. [CrossRef]

4. Ceballos, G.; Ehrlich, P.R.; Raven, P.H. Vertebrates on the brink as indicators of biological annihilation and the sixth mass extinction. Proc. Natl. Acad. Sci. USA 2020, 117, 13596-13602. [CrossRef]

5. Novacek, M.J. The Biodiversity Crisis: Losing What Counts; New Press: New York, NY, USA, 2001; pp. 1-223.

6. Jablonski, D. Extinction: Past and present. Nature 2004, 427, 589. [CrossRef]

7. Jablonski, D. Extinctions in the fossil record. Philos. Trans. R. Soc. Lond. Ser. B Biol. Sci. 1994, 344, 11-17. [CrossRef]

8. Bambach, R.K. Phanerozoic biodiversity mass extinctions. Annu. Rev. Earth Planet. Sci. 2006, 34, 127-155. [CrossRef]

9. Sepkoski, J.J., Jr. Patterns of Phanerozoic Extinction: A Perspective from Global Data Bases. In Global Events and Event Stratigraphy in the Phanerozoic; Walliser, P.D.O.H., Ed.; Springer: Berlin/Heidelberg, Germany, 1996; pp. 35-51.

10. Wignall, P.B. Extinction: A Very Short Introduction; Oxford University Press: Oxford, UK, 2019; 125p.

11. Elewa, A.M.T.; Abdelhady, A.A. Past, present, and future mass extinctions. J. Afr. Earth Sci. 2020, 162, 103678. [CrossRef]

12. Plotnick, R.E.; Smith, F.A.; Lyons, S.K. The fossil record of the sixth extinction. Ecol. Lett. 2016, 19, 546-553. [CrossRef] [PubMed]

13. Kirchner, J.W.; Weil, A. Delayed biological recovery from extinctions throughout the fossil record. Nature 2000, 404, 177-180. [CrossRef] [PubMed] 
14. Erwin, D.H. Lessons from the past: Biotic recoveries from mass extinctions. Proc. Natl. Acad. Sci. USA 2001, 98, 1399-1403. [CrossRef]

15. Alvarez, L.W.; Alvarez, W.; Asaro, F.; Michel, H.V. Extraterrestrial cause for the Cretaceous-Tertiary extinction. Science 1980, 208, 1095-1108. [CrossRef]

16. Raup, D.M.; Sepkoski, J.J., Jr. Periodic extinction of families and genera. Science 1986, 231, 833-836. [CrossRef]

17. Erwin, D.H. The Permo-Triassic extinction. Nature 1994, 367, 231-236. [CrossRef]

18. Wooldridge, S.A. Mass extinctions past and present: A unifying hypothesis. Biogeosci. Discuss. 2008, 5, 2401-2423. [CrossRef]

19. Kaiho, K.; Kajiwara, Y.; Nakano, T.; Miura, Y.; Kawahata, H.; Tazaki, K.; Ueshima, M.; Chen, Z.; Shi, G.R. End-Permian catastrophe by a bolide impact: Evidence of a gigantic release of sulfur from the mantle. Geology 2001, 29, 815-818. [CrossRef]

20. Yin, H.; Feng, Q.; Baud, A.; Xie, S.; Benton, M.J.; Lai, X.; Bottjer, D.J. The prelude of the end-Permian mass extinction predates a postulated bolide impact. Int. J. Earth Sci. 2007, 96, 903-909. [CrossRef]

21. Blackburn, T.J.; Olsen, P.E.; Bowring, S.A.; McLean, N.M.; Kent, D.V.; Puffer, J.; McHone, G.; Rasbury, E.T.; Et-Touhami, M. Zircon $\mathrm{U}-\mathrm{Pb}$ geochronology links the end-Triassic extinction with the Central Atlantic Magmatic Province. Science 2013, 340, 941-945. [CrossRef] [PubMed]

22. Schoene, B.; Samperton, K.M.; Eddy, M.P.; Keller, G.; Adatte, T.; Bowring, S.A.; Khadri, S.F.R.; Gertsch, B. U-Pb geochronology of the Deccan Traps and relation to the end-Cretaceous mass extinction. Science 2015, 347, 182-184. [CrossRef] [PubMed]

23. Ruban, D.A. Paleozoic-Mesozoic Eustatic Changes and Mass Extinctions: New Insights from Event Interpretation. Life 2020, 10, 281. [CrossRef]

24. Bond, D.P.; Grasby, S.E. Late Ordovician mass extinction caused by volcanism, warming, and anoxia, not cooling and glaciation. Geology 2020, 48, 777-781. [CrossRef]

25. Li, G.; Liao, W.; Li, S.; Wang, Y.; Lai, Z. Different triggers for the two pulses of mass extinction across the Permian and Triassic boundary. Sci. Rep. 2021, 11, 6686. [CrossRef] [PubMed]

26. Kaiho, K.; Aftabuzzaman, M.; Jones, D.S.; Tian, L. Pulsed volcanic combustion events coincident with the end-Permian terrestrial disturbance and the following global crisis. Geology 2021, 49, 289-293. [CrossRef]

27. Chiarenza, A.A.; Farnsworth, A.; Mannion, P.D.; Lunt, D.J.; Valdes, P.J.; Morgan, J.V.; Allison, P.A. Asteroid impact, not volcanism, caused the end-Cretaceous dinosaur extinction. Proc. Natl. Acad. Sci. USA 2020, 117, 17084-17093. [CrossRef]

28. Dzombak, R.M.; Sheldon, N.D.; Mohabey, D.M.; Samant, B. Stable climate in India during Deccan volcanism suggests limited influence on K-Pg extinction. Gondwana Res. 2020, 85, 19-31. [CrossRef]

29. Lyons, S.L.; Karp, A.T.; Bralower, T.J.; Grice, K.; Schaefer, B.; Gulick, S.P.; Morgan, J.V.; Freeman, K.H. Organic matter from the Chicxulub crater exacerbated the K-Pg impact winter. Proc. Natl. Acad. Sci. USA 2020, 117, 25327-25334. [CrossRef] [PubMed]

30. Hu, D.; Li, M.; Chen, J.; Luo, Q.; Grasby, S.E.; Zhang, T.; Yuan, S.; Xu, Y.; Finney, S.C.; Sun, Y.; et al. Major volcanic eruptions linked to the Late Ordovician mass extinction: Evidence from mercury enrichment and $\mathrm{Hg}$ isotopes. Glob. Planet. Chang. 2021, 196, 103374. [CrossRef]

31. Cooper, R.A.; Sadler, P.M.; Munnecke, A.; Crampton, J.S. Graptoloid evolutionary rates track Ordovician-Silurian global climate change. Geol. Mag. 2014, 151, 349-364. [CrossRef]

32. Kaiho, K.; Miura, M.; Tezuka, M.; Hayashi, N.; Jones, D.S.; Oikawa, K.; Casier, J.-G.; Fujibayashi, M.; Chen, Z.-Q. Coronene, mercury, and biomarker data support a link between extinction magnitude and volcanic intensity in the Late Devonian. Glob. Planet. Chang. 2021, 199, 103452. [CrossRef]

33. Rakociński, M.; Marynowski, L.; Pisarzowska, A.; Bełdowski, J.; Siedlewicz, G.; Zatoń, M.; Perri, M.C.; Spalletta, C.; Schönlaub, H.P. Volcanic related methylmercury poisoning as the possible driver of the end-Devonian Mass Extinction. Sci. Rep. 2020, 10, 7344. [CrossRef]

34. Claeys, P.; Casier, J.; Margolis, S.V. Mircotektites and mass extinctions: Evidence for a Late Devonian asteroid impact. Science 1992, 257, 1102-1104. [CrossRef]

35. Tobase, T.; Yoshiasa, A.; Komatsu, T.; Maekawa, T.; Hongu, H.; Okube, M.; Arima, H.; Sugiyama, K. Titanium local coordination environments in Cretaceous-Paleogene and Devonian-Carboniferous boundary sediments as a possible marker for large meteorite impact. Phys. Chem. Miner. 2019, 46, 675-685. [CrossRef]

36. Marshall, J.E.; Lakin, J.; Troth, I.; Wallace-Johnson, S.M. UV-B radiation was the Devonian-Carboniferous boundary terrestrial extinction kill mechanism. Sci. Adv. 2020, 6, eaba0768. [CrossRef]

37. He, T.; Dal Corso, J.; Newton, R.J.; Wignall, P.B.; Mills, B.J.; Todaro, S.; Di Stefano, P.; Turner, E.C.; Jamieson, R.A.; Randazzo, V.; et al. An enormous sulfur isotope excursion indicates marine anoxia during the end-Triassic mass extinction. Sci. Adv. 2020, 6, eabb6704. [CrossRef]

38. Punekar, J.; Keller, G.; Adatte, T.; Khozyem, H.M.; Font, E.; Spangenberg, J. A multi-proxy approach to decode the end-cretaceous mass extinction. Palaeogeogr. Palaeoclimatol. Palaeoecol. 2016, 441, 116-136. [CrossRef]

39. Font, E.; Adatte, T.; Sial, A.N.; Lacerda, L.D.; De Keller, G.; Punekar, J. Mercury Anomaly, Deccan Volcanism, and the endCretaceous mass extinction. Geology 2016, 44, 171-174. [CrossRef]

40. Font, E.; Adatte, T.; Andrade, M.; Keller, G.; Bitchong, A.M.; Carvallo, C.; Ferreira, J.; Diogo, Z.; Mirão, J. Deccan volcanism induced high-stress environment during the Cretaceous-Paleogene transition at Zumaia, Spain: Evidence from magnetic, mineralogical and biostratigraphic records. Earth Planet. Sci. Lett. 2018, 484, 53-66. [CrossRef] 
41. Stehlin, H.G. Remarques sur les faunules de mammifères des couches éocènes etoligocènes du Bassin de Paris. Bull. Soc. Géol. Fr. 1910, 9, 488-520.

42. Hooker, J.J.; Grimes, S.T.; Mattey, D.P.; Collinson, M.E.; Sheldon, N.D. Refined correlation of the UK late Eocene-early Oligocene Solent Group, and timing of its climate history. In The Late Eocene Earth: Hothouse, Icehouse and Impacts; Koeberl, C., Montanari, A., Eds.; Special Paper 452; Geological Society of America: Boulder, CO, USA, 2009; pp. 179-195.

43. Van Dam, J.A.; Aziz, H.A.; Sierra, M.Á.Á.; Hilgen, F.J.; van den Hoek Ostende, L.W.; Lourens, L.J.; Laurens, L.J.; Mein, P.; van der Meulen, A.J.; Pelaez-Campomanes, P. Long-period astronomical forcing of mammal turnover. Nature 2006, 443, 687-691. [CrossRef] [PubMed]

44. Turchetto-Zolet, A.C.; Pinheiro, F.; Salgueiro, F.; Palma-Silva, C. Phylogeographical patterns shed light on evolutionary process in South America. Mol. Ecol. 2013, 22, 1193-1213. [CrossRef] [PubMed]

45. Bibi, F.; Kiessling, W. Continuous evolutionary change in Plio-Pleistocene mammals of eastern Africa. Proc. Natl. Acad. Sci. USA 2015, 112, 10623-10628. [CrossRef]

46. Head, M.J.; Gibbard, P.L. Early-Middle Pleistocene transitions: Linking terrestrial and marine realms. Quat. Int. 2015, 389, 7-46. [CrossRef]

47. Crampton, J.S.; Cody, R.D.; Levy, R.; Harwood, D.; McKay, R.; Naish, T.R. Southern Ocean phytoplankton turnover in response to stepwise Antarctic cooling over the past 15 million years. Proc. Natl. Acad. Sci. USA 2016, 113, 6868-6873. [CrossRef] [PubMed]

48. Palombo, M.R. Faunal dynamics in SW Europe during the late Early Pleistocene: Palaeobiogeographical insights and biochronological issues. Comptes Rendus Palevol 2018, 17, 247-261. [CrossRef]

49. Rossi, V.; Azzarone, M.; Capraro, L.; Faranda, C.; Ferretti, P.; Macrì, P.; Scarponi, D. Dynamics of benthic marine communities across the Early-Middle Pleistocene boundary in the Mediterranean region (Valle di Manche, Southern Italy): Biotic and stratigraphic implications. Palaeogeogr. Palaeoclimatol. Palaeoecol. 2018, 495, 127-138. [CrossRef]

50. Suc, J.P.; Popescu, S.M.; Fauquette, S.; Bessedik, M.; Jiménez-Moreno, G.; Taoufiq, B.; Zheng, Z.; Médal, F.; Klotz, S. Reconstruction of Mediterranean flora, vegetation and climate for the last 23 million years based on an extensive pollen dataset. Ecol. Medit. 2018, 44, 53-85. [CrossRef]

51. Zhou, X.; Yang, J.; Wang, S.; Xiao, G.; Zhao, K.; Zheng, Y.; Shen, H.; Li, X. Vegetation change and evolutionary response of large mammal fauna during the Mid-Pleistocene Transition in temperate northern East Asia. Palaeogeogr. Palaeoclimatol. Palaeoecol. 2018, 505, 287-294. [CrossRef]

52. Rawlence, N.J.; Scofield, R.P.; McGlone, M.S.; Knapp, M. History repeats: Large scale synchronous biological turnover in avifauna from the Plio-Pleistocene and Late Holocene of New Zealand. Front. Ecol. Evol. 2019, 7, 158. [CrossRef]

53. Baker, P.A.; Fritz, S.C.; Battisti, D.S.; Dick, C.W.; Vargas, O.M.; Asner, G.P.; Martin, R.E.; Wheatley, A.; Prates, I. Beyond Refugia: New insights on Quaternary climate variation and the evolution of biotic diversity in tropical South America. In Neotropical Diversification: Patterns and Processes; Rull, V., Carnaval, A.C., Eds.; Springer: Cham, Switzerland, 2020; pp. 51-70.

54. Diz, P.; Peñalver-Clavel, I.; Hernández-Almeida, I.; Bernasconi, S.M. Environmental changes in the East Equatorial Pacific during the Mid Pleistocene Transition and implications for the Last Global Extinction of benthic foraminifera. Palaeogeogr. Palaeoclimatol. Palaeoecol. 2020, 539, 109487. [CrossRef]

55. Magri, D.; Parra, I.; Di Rita, F.; Ni, J.; Shichi, K.; Worth, J.R. Linking worldwide past and present conifer vulnerability. Quat. Sci. Rev. 2020, 250, 106640. [CrossRef]

56. O'Brien, K.; Patterson, D.B.; Biernat, M.D.; Braun, D.R.; Cerling, T.E.; McGrosky, A.; Faith, J.T. Ungulate turnover in the Koobi Fora Formation: Spatial and temporal variation in the Early Pleistocene. J. Afr. Earth Sci. 2020, 161, 103658. [CrossRef]

57. Pérez, L.; Correa-Metrio, A.; Cohuo, S.; González, L.M.; Echeverría-Galindo, P.; Brenner, M.; Curtis, J.; Kutterofl, S.; Stockhecke, M.; Schenk, F.; et al. Ecological turnover in Neotropical freshwater and terrestrial communities during episodes of abrupt climate change. Quat. Res. 2020, 101, 26-36. [CrossRef]

58. Pinsky, M.L.; Selden, R.L.; Kitchel, Z.J. Climate-driven shifts in marine species ranges: Scaling from organisms to communities. Ann. Rev. Mar. Sci. 2020, 12, 153-179. [CrossRef] [PubMed]

59. Couvreur, T.L.; Dauby, G.; Blach-Overgaard, A.; Deblauwe, V.; Dessein, S.; Droissart, V.; Hardy, O.J.; Harris, D.J.; Janssens, S.B.; Ley, A.C.; et al. Tectonics, climate and the diversification of the tropical African terrestrial flora and fauna. Biol. Rev. 2021, 96, 16-51. [CrossRef] [PubMed]

60. Koch, P.L.; Barnosky, A.D. Late Quaternary extinctions: State of the debate. Annu. Rev. Ecol. Evol. Syst. 2006, 37, 215-250. [CrossRef]

61. Surovell, T.A.; Grund, B.S. The associational critique of Quaternary overkill and why it is largely irrelevant to the extinction debate. Am. Antiq. 2012, 77, 672-687. [CrossRef]

62. Saltré, F.; Rodríguez-Rey, M.; Brook, B.W.; Johnson, C.N.; Turney, C.S.; Alroy, J.; Cooper, A.; Beeton, N.; Bird, M.I.; Fordham, D.A.; et al. Climate change not to blame for late Quaternary megafauna extinctions in Australia. Nat. Commun. 2016, 7, 10511. [CrossRef]

63. Lima-Ribeiro, M.S.; Diniz-Filho, J.A.F. Climate change, human overkill, and the extinction of megafauna: A macroecological approach based on pattern-oriented modelling. Evol. Ecol. Res. 2017, 18, 97-121.

64. Van Der Kaars, S.; Miller, G.H.; Turney, C.S.; Cook, E.J.; Nürnberg, D.; Schönfeld, J.; Kershaw, A.P.; Lehman, S.J. Humans rather than climate the primary cause of Pleistocene megafaunal extinction in Australia. Nat. Commun. 2017, 8, 14142. [CrossRef] 
65. Broughton, J.M.; Weitzel, E.M. Population reconstructions for humans and megafauna suggest mixed causes for North American Pleistocene extinctions. Nat. Commun. 2018, 9, 5441. [CrossRef]

66. Nagaoka, L.; Rick, T.; Wolverton, S. The overkill model and its impact on environmental research. Ecol. Evol. 2018, 8, 9683-9696. [CrossRef]

67. Price, G.J.; Louys, J.; Faith, J.T.; Lorenzen, E.; Westaway, M.C. Big data little help in megafauna mysteries. Nature 2018, 558, 23-25. [CrossRef] [PubMed]

68. Hocknull, S.A.; Lewis, R.; Arnold, L.J.; Pietsch, T.; Joannes-Boyau, R.; Price, G.J.; Moss, P.; Wood, R.; Dosseto, A.; Louys, J.; et al. Extinction of eastern Sahul megafauna coincides with sustained environmental deterioration. Nat. Comm. 2020, 11, 1-14. [CrossRef] [PubMed]

69. Jukar, A.M.; Lyons, S.K.; Wagner, P.J.; Uhen, M.D. Late Quaternary extinctions in the Indian Subcontinent. Palaeogeogr. Palaeoclimatol. Palaeoecol. 2020, 562, 110137. [CrossRef]

70. Lopes, R.P.; Pereira, J.C.; Kerber, L.; Dillenburg, S.R. The extinction of the Pleistocene megafauna in the Pampa of southern Brazil. Quat. Sc. Rev. 2020, 242, 106428. [CrossRef]

71. Seersholm, F.V.; Werndly, D.J.; Grealy, A.; Johnson, T.; Early, E.M.K.; Lundelius, E.L.; Winsborough, B.; Early Farr, G.; Toomey, R.; Anders, A.J.; et al. Rapid range shifts and megafaunal extinctions associated with late Pleistocene climate change. Nat. Commun. 2020, 11, 2770. [CrossRef]

72. Stewart, M.; Carleton, W.C.; Groucutt, H.S. Climate change, not human population growth, correlates with Late Quaternary megafauna declines in North America. Nat. Commun. 2021, 12, 965. [CrossRef] [PubMed]

73. Turner, S. Progress in the Formalisation of the Anthropocene GSSP. EGU General Assembly Conference Abstracts. held online 19-30 April, 2021, id.EGU21-3226 2021; Bibcode EGU21-3226. Available online: https:/ / ui.adsabs.harvard.edu/abs/2021EGUGA..23.32 $26 \mathrm{~T}$ (accessed on 19 May 2021).

74. Zalasiewicz, J.; Waters, C.N.; Ellis, E.C.; Head, M.J.; Vidas, D.; Steffen, W.; Thomas, J.A.; Horn, E.; Summerhayes, C.P.; Leinfelder, R.; et al. The Anthropocene: Comparing its meaning in geology (chronostratigraphy) with conceptual approaches arising in other disciplines. Earth's Future 2021, 9, e2020EF001896. [CrossRef]

75. Braje, T.J.; Erlandson, J.M. Human acceleration of animal and plant extinctions: A Late Pleistocene, Holocene, and Anthropocene continuum. Anthropocene 2013, 4, 14-23. [CrossRef]

76. Pimm, S.L.; Raven, P. Extinction by numbers. Nature 2000, 403, 843-845. [CrossRef]

77. May, R.M. The future of biological diversity in a crowded world. Curr. Sci. 2002, 82, 1325-1331.

78. Mace, G.M.; Collar, N.J.; Gaston, K.J.; Hilton-Taylor, C.; Akçakaya, H.R.; Leader-Williams, N.; Milner-Gulland, E.J.; Stuart, S.N. Quantification of extinction risk: IUCN's system for classifying threatened species. Conserv. Biol. 2008, 22, 1424-1442. [CrossRef] [PubMed]

79. Vié, J.C.; Hilton-Taylor, C.; Pollock, C.; Ragle, J.; Smart, J.; Stuart, S.N.; Tong, R. The IUCN Red List: A Key Conservation Tool. Wildlife in a Changing World: An Analysis of the 2008 IUCN Red List of Threatened Species; IUNC: Gland, Switzerland, 2009; pp. 1-159.

80. Newell, N.D. Adequacy of the fossil record. J. Paleontol. 1959, 33, 488-499.

81. Naimark, E.; Kirpotin, D.; Boeva, N.; Gmoshinskiy, V.; Kalinina, M.; Lyupina, Y.; Markov, A.; Nikitin, M.; Shokurov, A.; Volkov, D. Taphonomic experiments imply a possible link between the evolution of multicellularity and the fossilization potential of soft-bodied organisms. Ecol. Evol. 2020, 11, 1037-1056. [CrossRef]

82. Foote, M. Origination and extinction components of taxonomic diversity: General problems. Paleobiology 2000, 26, 74-102. [CrossRef]

83. Behrensmeyer, A.K.; Hill, A.P. (Eds.) Fossils in the Making: Vertebrate Taphonomy and Paleoecology (No. 69); University of Chicago Press: Chicago, IL, USA, 1988; pp. 1-345.

84. Lyman, R.L. Vertebrate Taphonomy; Cambridge University Press: Cambridge, UK, 1994; p. xxvi + 524.

85. Pimm, S.L.; Russell, G.J.; Gittleman, J.L.; Brooks, T.M. The future of biodiversity. Science 1995, 269, 347-350. [CrossRef] [PubMed]

86. DeVos, J.M.; Joppa, L.N.; Gittleman, J.L.; Stephens, P.R.; Pimm, S.L. Estimating the normal background rate of species extinction. Conserv. Biol. 2014, 29, 452-462. [CrossRef]

87. Plotnick, R.E.; Koy, K.A. The Anthropocene fossil record of terrestrial mammals. Anthropocene 2020, 29, 100233. [CrossRef]

88. MA (Millennium Ecosystem Assessment). Millennium Ecosystem Assessment Synthesis Report; Island Press: Washington, DC, USA, 2005.

89. IPBES. Global Assessment Report on Biodiversity and Ecosystem Services of the Intergovernmental Science-Policy Platform on Biodiversity and Ecosystem Services; IPBES Secretariat: Bonn, Germany, 2019.

90. Lamkin, M.; Miller, A.I. On the challenge of comparing contemporary and deep-time biological-extinction rates. BioScience 2016, 66, 785-789. [CrossRef]

91. Pimm, S.L.; Brooks, T.M. The sixth extinction: How large, where and when? In Nature and Human Society: The Quest for a Sustainable World; Raven, P.H., Williams, T., Eds.; National Academy Press: Washington, DC, USA, 2000; pp. 46-62.

92. Dirzo, R.; Young, H.S.; Galetti, M.; Ceballos, G.; Isaac, N.J.; Collen, B. Defaunation in the Anthropocene. Science 2014, 345, 401-406. [CrossRef]

93. Ceballos, G.; Ehrlich, P.R.; Dirzo, R. Biological annihilation via the ongoing sixth mass extinction signaled by vertebrate population losses and declines. Proc. Natl. Acad. Sci. USA 2017, 114, E6089-E6096. [CrossRef] 
94. IUCN. Summary Statistics. 2020. Available online: https://www.iucnredlist.org/resources/summary-statistics\#Summary (accessed on 19 May 2021).

95. WWF. Living Planet Report WWF (2020). In Living Planet Report 2020_Bending the Curve of Biodiversity Loss; Almond, R.E.A., Grooten, M., Petersen, T., Eds.; WWF: Gland, Switzerland, 2020; pp. 1-158.

96. Mora, C.; Tittensor, D.P.; Adl, S.; Simpson, A.G.; Worm, B. How many species are there on Earth and in the ocean? PLoS Biol. 2019, 9, e1001127. [CrossRef]

97. IUNC Sampled Red List Index for Plants. 2021. Available online: http://threatenedplants.myspecies.info (accessed on 19 May 2021).

98. Brummitt, N.; Bachman, S.P.; Moat, J. Applications of the IUCN Red List: Towards a global barometer for plant diversity. Endanger Species Res. 2008, 6, 127-135. [CrossRef]

99. Bachman, S.P.; Field, R.; Reader, T.; Raimondo, D.; Donaldson, J.; Schatz, G.E.; Lughadha, E.N. Progress, challenges and opportunities for Red Listing. Biol. Conserv. 2019, 234, 45-55. [CrossRef]

100. Pitman, N.C.; Jorgensen, P.M. Estimating the size of the world's threatened Flora. Science 2002, 298, 986-987. [CrossRef] [PubMed]

101. Rivers, M.; Beech, E.; Bazos, I.; Bogunić, F.; Buira, A.; Caković, D.; Carapeto, A.; Carta, A.; Cornier, B.; Fenu, G.; et al. European Red List of Trees; IUCN Red List of Threatened Species: Regional Assessment; International Union for Conservation of Nature and Natural Resources (IUCN): Cambridge, UK; Brussels, Belgium, 2019. [CrossRef]

102. IUNC. Table 4b: Plant Species (Kingdom: Plantae) by Class and Family. 2020. Available online: https://www.iucnredlist.org/ statistics (accessed on 19 May 2021).

103. Brooks, D.R.; Hoberg, E.P.; Boeger, W.A. The Stockholm Paradigm: Climate Change and Emerging Disease; University of Chicago Press: Chicago, IL, USA, 2019; pp. 1-409.

104. Rothman, D.H. Thresholds of catastrophe in the Earth system. Sci. Adv. 2017, 3, e1700906. [CrossRef] [PubMed]

105. Botkin, D.B.; Saxe, H.; Araujo, M.B.; Betts, R.; Bradshaw, R.H.; Cedhagen, T.; Chesson, P.; Dawson, T.P.; Etterson, J.R.; Faith, D.P.; et al. Forecasting the effects of global warming on biodiversity. Bioscience 2007, 57, 227-236. [CrossRef]

106. Combourieu-Nebout, N.; Bertini, A.; Russo-Ermolli, E.; Peyron, O.; Klotz, S.; Montade, V.; Fauquette, S.; Allen, J.; Fusco, F.; Goring, S.; et al. Climate changes in the central Mediterranean and Italian vegetation dy-namics since the Pliocene. Rev. Palaeobot. Palynol. 2015, 218, 127-147. [CrossRef]

107. Zhou, Z.; Ding, Y.; Shi, H.; Cai, H.; Fu, Q.; Liu, S.; Li, T. Analysis and prediction of vegetation dynamic changes in China: Past, present and future. Ecol. Indic. 2020, 117, 106642. [CrossRef]

108. Elias, S.A. 4 The Value of Insects in Paleoecology. Dev. Quat. Sci. 2010, 12, 39-51. [CrossRef]

109. Alter, S.E.; Meyer, M.; Post, K.; Czechowski, P.; Gravlund, P.; Gaines, C.; Rosenbaum, H.C.; Kaschner, K.; Turvey, S.T.; van der Plicht, J.; et al. Climate impacts on transocean dispersal and habitat in gray whales from the Pleistocene to 2100. Mol. Ecol. 2015, 24, 1510-1522. [CrossRef]

110. Baca, M.; Nadachowski, A.; Lipecki, G.; Mackiewicz, P.; Marciszak, A.; Popović, D.; Socha, P.; Stefaniak, K.; Wojtal, P. Impact of climatic changes in the Late Pleistocene on migrations and extinction of mammals in Europe: Four case studies. Geol. Q. 2017, 61, 291-304. [CrossRef]

111. Barnosky, A.D. Transforming the global energy system is required to avoid the sixth mass extinction. MRS Energy Sustain. 2015, 2, 1-13. [CrossRef]

112. Schloss, C.A.; Nuñez, T.A.; Lawler, J.J. Dispersal will limit ability of mammals to track climate change in the Western Hemisphere. Proc. Natl. Acad. Sci. USA 2012, 109, 8606-8611. [CrossRef]

113. Pinsky, M.L.; Eikeset, A.M.; McCauley, D.J.; Payne, J.L.; Sunday, J.M. Greater vulnerability to warming of marine versus terrestrial ectotherms. Nature 2019, 569, 108-111. [CrossRef]

114. Young, H.S.; McCauley, D.J.; Galetti, M.; Dirzo, R. Patterns, Causes, and Consequences of Anthropocene Defaunation. Ann. Rev. Ecol. Evol. Syst. 2016, 47, 333-358. [CrossRef]

115. Borja, A.; Andersen, J.H.; Arvanitidis, C.D.; Basset, A.; Buhl-Mortensen, L.; Carvalho, S.; Dafforn, C.D.; Devlin, M.J.; EscobarBriones, E.G.; Grenz, C.; et al. Past and future grand challenges in marine ecosystem ecology. Front. Mar. Sci. $2020,7,362$. [CrossRef]

116. Kirkman, S.P.; Baliwe, N.G.; Nhleko, J.; Pfaff, M.C. Ecosystem health and human wealth-A comparison of sub-Saharan African Large Marine Ecosystems. Environ. Dev. 2020, 36, 100551. [CrossRef]

117. Scholes, R.J.; Biggs, R. A biodiversity intactness index. Nature 2005, 434, 45-49. [CrossRef]

118. Newbold, T.; Hudson, L.N.; Arnell, A.P.; Contu, S.; De Palma, A.; Ferrier, S.; Hill, S.L.L.; Hoskins, A.J.; Lysenko, I.; Phillips, H.R.; et al. Has land use pushed terrestrial biodiversity beyond the planetary boundary? A global assessment. Science 2016, 353, 288-291. [CrossRef]

119. Díaz, S.; Settele, J.; Brondízio, E.S.; Ngo, H.T.; Agard, J.; Arneth, A.; Balvanera, P.; Brauman, K.A.; Butchart, S.H.M.; Chan, K.M.A.; et al. Pervasive human-driven decline of life on Earth points to the need for transformative change. Science 2019, 366, eaax3100. [CrossRef] [PubMed]

120. IPBES. Summary for Policymakers of the Global Assessment Report on Biodiversity and Ecosystem Services of the Intergovernmental Science-Policy Platform on Biodiversity and Ecosystem Services; Díaz, S., Settele, J., Brondízio, E., Ngo, H., Guèze, M., Agard, J., Arneth, A., Balvanera, P., Brauman, K., Butchart, S., et al., Eds.; IPBES Secretariat: Bonn, Germany, 2019; pp. 1-56.

121. Briggs, J.C. Emergence of a sixth mass extinction? Biol. J. Linn. Soc. 2017, 122, 243-248. [CrossRef] 
122. MacLeod, N. The Great Extinctions; Firefly Books: Buffalo, NY, USA, 2013; p. 208.

123. Everard, M.; Johnston, P.; Santillo, D.; Staddon, C. The role of ecosystems in mitigation and management of Covid-19 and other zoonoses. Environ. Sci. Policy 2020, 111, 7-17. [CrossRef] [PubMed]

124. Wang, Y.; Shipley, B.R.; Lauer, D.A.; Pineau, R.M.; McGuire, J.L. Plant biomes demonstrate that landscape resilience today is the lowest it has been since end-Pleistocene megafaunal extinctions. Glob. Chang. Biol. 2020, 26, 5914-5927. [CrossRef] [PubMed] 